\title{
Party organizational change and ICTs: The growth of a virtual grassroots?
}

DOI:

$10.1177 / 1461444812457329$

\section{Document Version}

Accepted author manuscript

Link to publication record in Manchester Research Explorer

\section{Citation for published version (APA):}

Gibson, R. K., Gillan, K., Greffet, F., Lee, B. J., \& Ward, S. (2013). Party organizational change and ICTs: The growth of a virtual grassroots? New Media and Society, 15(1), 31-51. https://doi.org/10.1177/1461444812457329

\section{Published in:}

New Media and Society

\section{Citing this paper}

Please note that where the full-text provided on Manchester Research Explorer is the Author Accepted Manuscript or Proof version this may differ from the final Published version. If citing, it is advised that you check and use the publisher's definitive version.

\section{General rights}

Copyright and moral rights for the publications made accessible in the Research Explorer are retained by the authors and/or other copyright owners and it is a condition of accessing publications that users recognise and abide by the legal requirements associated with these rights.

\section{Takedown policy}

If you believe that this document breaches copyright please refer to the University of Manchester's Takedown Procedures [http://man.ac.uk/04Y6Bo] or contact uml.scholarlycommunications@manchester.ac.uk providing relevant details, so we can investigate your claim.

\section{OPEN ACCESS}




\title{
Party Organizational Change and ICTs: The Growth of a Virtual Grassroots?
}

\author{
Rachel K. Gibson, Fabienne Greffet, Benjamin J. Lee, \& Stephen Ward
}

Note: This is the author-accepted manuscript version of a paper published in New Media \& Society. The final, authoritative version is available via SAGE at:

https://doi.org/10.1177/1461444812457329

Cite: Gibson, R. K., Gillan, K., Greffet, F., Lee, B. J., \& Ward, S. (2013). Party

organizational change and ICTs: The growth of a virtual grassroots? New Media \& Society, 15(1), 31-51. https://doi.org/10.1177/1461444812457329

\begin{abstract}
This paper examines the emergence of unofficial party blog sites in the UK using a multimethod approach. The key research questions examined are why the blogs were established, what topics they cover and particularly whether they are critical of the parties, how popular they are and who uses them audiences and how far party and blogs link together to form coherent online networks. The role of political context is examined by conducting our analyses at two time points: May and October/November 2010. Our findings show the blogs occupy an important alternative space for party debate with more dissent voiced outside elections and less connectivity to party sites in evidence. Overall, we argue the blogs are ultimately supportive of parties', offering grassroots opportunities for information gathering and discussion that would otherwise be unavailable.
\end{abstract}




\section{Introduction: Organizational Change in Political Parties and ICTs}

To date, examinations of new ICTs and political parties have centered on the public arena of e-campaigns and electioneering (Bimber and Davis, 2003; Lusoli and Jankowski, 2005; Author 2008a; Foot and Schneider, 2007). By contrast, the impact of ICTs on intra-party affairs has been considerably less explored. Yet, arguably, it is in the relatively less public world of party organizations that ICTs are now beginning to facilitate significant change. One striking recent trend in the UK has been growth in more informal bottom-up uses of userdriven Web 2.0 technologies by party members and affiliated networks. Alternative unofficial partisan spaces have emerged, primarily around the blogosphere but also via social networking tools such as Facebook and Twitter. Partisan blog networks have developed in the UK, centred on: (1) individual personalities, such as Iain Dale (former Conservative parliamentary candidate) and Guido Fawkes (self styled, anti government libertarian); (2) a growing number of MPs from all parties, with around 6\% of MPs blogging in 2007 increasing to around $11 \%$ by late 2008 (Author 2008b; Jackson and Lilleker, 2008; Hansard Society, 2008); and (3) collective blog platforms affiliated to the main parties. It is primarily that latter phenomenon on which this paper focuses. Since 2005 the development of four particular unofficial party blogs - Conservative Home (CH), Labour Home (LH), Labour List (LL) and Liberal Democrat Voice (LDV) - have gained prominence. We examine these sites in order to better understand the party blogosphere and its implications for official party organizations. Do party blogs ultimately present a challenge to parties' status, serving as a replacement for member discussion, support and activism? Or are they a complementary development, helping parties to re-energize their base, drawing in new supporters and opening up additional networked 'space' for debate? We use a multi-method approach to address these questions and qualitative and quantitative data detailed below.

Academic attention to parties' use of new ICTs to date has focused primarily on their 
engagement in e-campaigning, investigations of their internal uses of new ICTs have been increasing. Against a backdrop of organizational problems including declining memberships, levels of activism, shortages in funding, and the weakening of links into civil society through falls in partisan attachment (Seyd \& Whiteley, 2002; Needham, 2005; Webb, 2006; Norris, 2002), parties across liberal democracies have shown increasing interest in the use of new technologies for organizational renewal.

Much of the work on parties' internal and organizational uses of ICTs has been speculative and non-empirical. Early writers, such as Rheingold (1994), Negroponte (1995), and Budge (1996) offered predictions about parties' declining role in the Internet era as part of the wider erosion of representative institutions and increased use of direct methods of citizen input. The continuance of the state and collapse of the dot.com bubble challenged these more radical interpretations of new ICTs impact and more moderate and party-driven accounts followed, with authors coalescing around two alternative scenarios. One being the emergence of a more decentralized, transparent and grass-roots led 'cyber-democratic' party model. The other a trajectory of an increasingly centralized and 'techno-elite' dominated organizations that would erode members' collective identity and power to hold their leaders accountable (Smith, 1998, 2000; Lofgren \& Smith, 2003; Lipow \& Seyd, 1996). Subsequent work by Margetts (2006) and Saglie and Heider (2005) reinforced these dual possibilities but as two sides of a single new party model - the 'cyberparty' or 'network party' - in which members were afforded more flexible channels for participation and opportunities to form and join looser issue and policy-based networks. Levels and timing of individuals' involvement could vary, ranging from simply receiving regular news updates, to donating funds and contributing feedback on an individual policy or issue basis. Such easy exit and entry barriers was also seen to create the possibility for a more passive and floating support base less able to hold leaders accountable, and the emergence of a narrower digital elite that displaces the more traditional 
activist base.

Empirical investigation of these projections has been limited to date. Smith and Webster (1995) provided a brief account of the uptake of computing and information systems within the three main parties in the UK from the 1980s onward. Their analysis revealed that usage was confined to an already active IT-literate minority and that the technology was regarded as a labour-saving device rather than a means for promoting grass-roots activity. (Author 1999) study of national party elites' attitudes toward internal computerized communication systems confirmed Smith's picture of a lack of interest in more participatory uses of the technology, particularly within in the major parties. Subsequent analysis of Labour and Liberal Democrat party members presented a more positive scenario, however, with new ICTs appealing more strongly to the younger cohort. Online joiners, however, were found to be more passive than those joining through traditional means, whilst IT also served to deepen activism amongst the already active, creating an internal digital divide (Author, 2003, 2004).

In general then, it seems that parties' internal adaptation to new ICTs may be promoting a more centralized mode of operation and a narrowing of their support base. However the limited and rather dated nature of the evidence supporting this argument raises questions about how robust such conclusions are. Also parties' have undertaken some new online initiatives in the social media era that appear to challenge. The development of the party blogs investigated here is one prominent example of how new ICTs may be helping to democratize and revitalize internal party politics. We explore this further below.

\section{Research Questions, Data and Methods}

In light of the above discussion, we sought to carry out a broad-based exploration of the role of these new grassroots online spaces and their relationship with more formal party websites. In particular we focus, firstly, on inter-party comparisons to discover whether the three major UK parties and their associated bloggers and audiences take a similar approach to online 
communication and networking. Secondly, we are interested in an intra-party perspective that is capable of understanding the relation between the parties and their grassroots and blogger communities. The development of these online communities raises important questions in terms of the quality and inclusiveness of political discussion around party structures, which we operationalized with five sets of concrete research questions:

1. What are the origins of the partisan blog sites and why were they created?

2. Who contributes to the sites and what type of content is present? Particularly, how much dissent and criticism of the party is featured?

3. How wide is the reach of these sites in the Web and who form the audience for such sites?

4. To what extent do the parties' official websites and the partisan and independent blogs form a cohesive online issue network? Or, do they form a separate alternative and independent network for party political discussion?

5. How does the wider political context, understood in terms of position in the election cycle and party incumbency, affect the contents and structure of party and blog websites?

Given the range of questions and exploratory nature of the research a multi-method strategy was considered appropriate. Four modes of data collection and analysis were used to address our core questions:

(1) 17 semi-structured interviews were conducted between November 2008 and January 2009 with party officials, bloggers and blog editors. The interview data was used to provide background information on: the context and origins of the blog sites, the function, purpose and audience for the blog sites and to supplement findings on our other research questions;

(2) Qualitative content analyses of three blog sites ( $\mathrm{CH}, \mathrm{LL}$ and LDV) were used to address question 2. ${ }^{1}$ Specifically, we examined the amount and type of postings across two time 
points: i) during the last week of the election campaign (1-7 May 2010) and ii) after the election (10-16 October 2010). Capturing data from these two time points meant that we could assess both the effect of the election campaign on the sites and the new (ConservativeLiberal coalition) government. Given the decline of LH in terms of updated content by 2010, we replaced it with the LL site which had become more prominent by this point. As well as the number and frequency of postings we identified the source of the posts (editors, politicians/official party personnel, or private individuals), and the tone of postings. This latter categorization used five basic codes - supportive, neutral, critical/challenging of the party, opponent focused and other. This was done to assess how far the sites really offered an alternative voice to, or challenged, their party leadership.

(3) Audience/user statistics, Two data sources were utilized to measure the sites' reach (question 3). The first was a range of site statistics produced by Alexa.com, a web information and traffic ranking service. The data used by the service are compiled primarily from its large body of registered Alexa Tool Bar users although they also incorporate other 'unspecified' sources. The data reported here included traffic rankings, the percentage change in traffic to the site over a three-month period (calculated in terms of overall global Internet users), and the number of inlinks a site receives. A second source of information on these sites' audience was provided via an online survey of users of the LDV blog fielded in September-October 2009. The survey gathered a range of demographic and attitudinal data on site visitors as well as more specific information about their motives in using the site and perceptions of its importance. $^{2}$

(4) Hyperlink network analysis was conducted using two publicly available social network analysis software applications. These tools allowed analysis of the structure and content of online networks occupied by blogs in relation to other party related sites (question 4). Specifically, Issue Crawler was used to collect the hyperlink data and map the basic 
parameters of the relevant networks. More in-depth analysis and visualization of the contents and properties of the blog networks was undertaken with a Microsoft Excel template called NodeXL. ${ }^{3}$ Two stages of link harvesting with Issue Crawler were performed. The first stage focused on collecting the links contained in homepages of the official party website and the relevant party blog, so a total of three 'seedsets' of links were created - one for Labour and LH/LL, the Conservatives and CH, and the Liberal Democrats and LDV. In a second stage we created larger seed sets of links that were taken from the official profiles of parties and blogs on the most popular social media websites (see Appendix for full details). Both stages were performed across our two time points of May and October.

(5) The final question on the impact of political context was addressed by cumulating and comparing the findings of the content analysis, usage statistics and hyperlink analysis over two time points. May 2010 captured activity during the general election campaign, while the second was October- November 2010 provided a non-election 'peace-time' political context.

\section{Origins: The Rise of Unofficial Party Blogs}

$\mathrm{CH}$ pioneered the unofficial collective partisan blog format just before the 2005 election with LH and LDV emerging in the following 18 months, whilst Labourlist (LL) is a more recent addition having been created in early 2009. Indeed, the initial success of $\mathrm{CH}$ in 2005 acted as a catalyst motivating other parties' responses. As the editors' welcome post on LH admitted:

Last year Tim Montgomerie set up www.conservativehome.com and it seems to have done a good job at focusing grassroots Tory opinion - so we thought, "why can't we do something like that?" (LabourHome, 20 June 2006).

All the sites claim that representing the grassroots or providing a space for supporters' voices to be heard is one of their primary goals. The tag lines of the sites are indicative, with LDV described as "our place to talk", LH as "back to the grassroots" and LL as "Labour's 
biggest independent grassroots e-network". Similarly, Montgomerie's reflections on the fourth birthday of $\mathrm{CH}$ list 10 broad aims and achievements including representing the grassroots, protecting party democracy, campaigning for a balanced Conservative message and initiating campaigns (CH, April 2009). The editor's initial post explains LDV as a "place for activists and party members to have a conversation... This place is intended to be by activist for activists... It is not an official blog" (LDV, 9 September 2006).

Despite claims to represent the grassroots, none of the sites were created by outsiders or ordinary supporters. $\mathrm{CH}$ was launched by Tim Montgomerie an ex-senior aide to former Conservative leader Iain Duncan-Smith and was funded by Stephan Shakespeare director of the polling organization Yougov. LDV was started by Rob Fenwick who was the party Internet Campaigns Officer at the 2005 election. Fenwick was joined subsequently by Mark Pack an early regular contributor and previously the party's Head of Innovations. The remaining editors were largely a mixture of local councillors or activists. At LH, founder and editor Alex Hilton had been PPC for Labour in 2005 and his co-founder Jag Singh had worked on John Kerry's 2004 US presidential campaign. Although initially unsponsored, LH was bought by Mike Danson, publisher of the left of centre New Statesman magazine in 2008, although Hilton remained the editor ${ }^{4}$. LL is comparable to $\mathrm{LH}$ in terms of its quasi official status (unlike the Left Foot Forward blog for instance, which is promoted as a nonaligned source for left-wing progressives). In its early days LL was enmeshed in a political scandal over leaked emails designed to discredit leading Conservatives. Despite its rocky start, LL has increasingly strengthened its position and profile, eclipsing LH as the most prominent independent party blog of the centre left.

Over time, $\mathrm{CH}$ has developed into the most popular and influential of the sites under investigation. It has developed the largest audience of the three sites (see below for details) and regularly gains coverage in the mainstream media. Tim Montgomerie appears frequently 
on radio and television news shows to offer the voice of the Conservative grassroots and contributes articles to the broadsheet press. In part, the media coverage and attention is not surprising since $\mathrm{CH}$ has three full-time staff dedicated to the site (Montgomerie, ex Daily Telegraph journalist Jonathan Isaby and former MP Paul Goodman). However, it is not simply the mechanics or the professionalism of the site that explain the development of $\mathrm{CH}$. It established a prominent voice and its grassroots credentials almost from the start. It quickly became an influential voice in internal party debates and an agenda setter. Within months of its creation $\mathrm{CH}$ led opposition to then leader Michael Howard's attempt to abolish onemember one-vote rule for the election of the party leader. It also built its audience through its coverage of the subsequent 2005 leadership election battle. Nor has current leader David Cameron always had a smooth ride from $\mathrm{CH}$ especially in the initial stages of his leadership. $\mathrm{CH}$ has been critical of the so-called 'A list' of parliamentary candidates drawn up by central office to widen the social base of the party representatives. More recently, it has also raised questions about future Conservative spending plans and argued for a reduced role for the state.

By comparison to $\mathrm{CH}, \mathrm{LDV}, \mathrm{LL}$ and LH occupy a lower profile both within and outside of their respective parties and have yet to exercise as strong an influence on policy. In Autumn 2008, LH did make headlines in the mainstream media, (and was criticized by the party), for running a poll of its members that called for Gordon Brown's to resign as party leader. LL clearly has strong aspirations in this direction, identifying itself as 'an independent progressive blog providing a platform for open debate about centre-left issues and the future of the Labour movement'.

\section{Contributors and Content: The Emergence of Grassroots Communities?}

All three sites in our content analysis ( $\mathrm{CH}$, LDV and LL) were regularly updated with multiple posts per day. The volume of posts was, unsurprisingly, more intense in the last 
week of the election campaign for all the sites (especially $\mathrm{CH}$ and LDV). As Table 1 shows, $\mathrm{CH}$ clearly dwarfs the other two, and particularly LL, in terms of the quantity, regularity and range of postings (averaging $21 \& 16$ per day in the election and peace time periods respectively). That is nearly three times as many posts as LL in the election week period. $\mathrm{CH}$ effectively offers a comprehensive, professionalized news service with large numbers of links to mainstream media and blog stories relating to key issues and conservative affairs and personalities. There are extensive links to a video site with clips of the latest political interviews and speeches. The other two sites have more of a feel of traditional blogs, although they do mirror the $\mathrm{CH}$ format on a more limited scale. They both have regular daily links to news stories and audio-video coverage. LDV also provides a member-only discussion forum in addition to the public blog site.

\section{[TABLE 1 ABOUT HERE]}

In both periods, editorial teams dominated the postings on all three sites but especially $\mathrm{CH}$ and LDV and most particular in the election period. In the election campaign, over $90 \%$ posts on LDV came from the editorial team and $83 \%$ on $\mathrm{CH}$. Whilst this figure lessens considerably in October, editors still account for over half the postings on all the sites. There are though some differences in terms of posters. Whilst all three have grassroots input, this is arguably greater for LDV and especially for LL. LL postings contained contributions from both ordinary party members and well-known figures such as Alistair Campbell and Ken Livingstone. Whilst elected party representatives did post on all three sites they did so in relatively limited numbers and hardly at all during the election campaign. Overall, $\mathrm{CH}$ tends to have most regular postings by elected officials and other quasi-official party voices and groups. Again, these differences partly reflect the structure of the sites. For instance, $\mathrm{CH}$ has regularized and formalized features, sections and posters. Besides the editors, there are regular posts from right of centre thinks tanks and internal pressure groups such as Policy 
Exchange, Taxpayers Alliance and the Social Market Foundation.

We also looked at the tone of postings and the level of criticism of the official party. Here a number of trends stand out (see Table 2). Firstly, the level of questioning/challenging posts during election time is very low. Of the four posts which might be considered to have mildly challenging comments three came the day after the election, raising questions about the campaign or warning party leaders not to do deals with other parties. The blogs seem to have taken on a more supportive role during the campaign with the vast majority of posts offering either partisan support for the party or focused on attacking opponents. In the postelection period we see a rise in challenging posts on $\mathrm{CH}$ and LDV. In part, this can be accounted for by tensions in maintaining the coalition between the two parties. The biggest issue of contention, especially for LDV, was the controversial issue of university tuition fees that surfaced as the main political issue during this week. Ten of the twelve critical posts were on this issue alone on LDV. In the case of $\mathrm{CH}$, some of the challenging posts relate to the issue of the European budget where posters wanted to push the leadership towards an more eurosceptic position. Thirdly, and somewhat surprisingly given the problems of Labour election campaign and subsequent leadership debate, critical posts on LL were almost absent. Indeed, in the post-election period, there appeared to be a considerable shift towards attacking the new government's policies. Since our October study was conducted in the immediate aftermath of Ed Miliband's election as party leader, it could be that the findings indicate a coming together of the party to support the new leader after a period of internal party debate. Finally, there was little outright hostility or open criticism in any of the postings. The tone of challenging posts remained polite, although the comments sections on all three sites allowed significant amount of vitriol to be aimed at all the parties.

\section{[TABLE 2 ABOUT HERE]}

While the extent of commentary had fallen after the election there remains a healthy 
discussion in response to posts on all the sites. Most notably, the level of debate on LDV had risen since the controversial decision of the party to back proposals for increases to university fees. This was an issue that had drawn more interest and feedback than any previous debate according to LDV editors.

Overall, the content study indicates that these sites represent active communities for partisan supporters. They allow a growing diversity of voices to be heard and could certainly be seen as good indicators of issues important to the party grassroots. They all follow similar patterns in terms of broad content and structure although $\mathrm{CH}$ represents the most professionalized and has a stronger focus on news coverage. The differences in campaign mode and peace time study suggest that such sites can function in a more supportive manner at election time, focusing more on internal debate outside of that particularly competitive context.

\section{Audiences: Reaching Out or Reaching in?}

Beyond the origins and contents of these sites, we were also interested to examine their significance and potential impact in the wider web sphere. To do this, we utilized two data sources - Alexa statistics on site rankings based on visitors and an online survey of LDV users.

The Alexa ranking results displayed in Table 3 demonstrate that the Conservatives are the most prominent political force online. The party's official homepage and $\mathrm{CH}$ are the most frequently visited of all the sites investigated and enjoy the highest number of inlinks, i.e. links directed to them from other sites. The only exception here is during the May 2010 election period when the Liberal Democrats rose slightly higher in the rankings than either site; a surge of interest undoubtedly related to the higher profile of Liberal Democrat leader Nick Clegg after he performed beyond expectations in televised leadership debates. Comparing the performance of the blogs to that of the party sites overall, we can see the latter 
proving more popular during the election and the former asserting their dominance in the post-election period. The traffic rankings (where lower scores mean higher ranking) show that the major parties' sites were ranked within the top 60,000 of all websites analysed by Alexa and within the top 1,000 UK sites during the election in May. The only blog to join the parties in this level of prominence was $\mathrm{CH}$. Post-election, while $\mathrm{CH}$ and $\mathrm{LH}$ both fall in overall popularity, the latter spectacularly so, both LL and LDV by contrast appear to maintain and even increase their audiences; LL on the UK rankings and LDV on the global rankings. Such findings are interesting in that they indicate that party sites are of value during an election period, but quickly fall off in popularity afterward. Blogs on the other hand would appear to have a more stable audience.

\section{[TABLE 3 ABOUT HERE]}

Alexa provides statistics on the origins of the traffic arriving to the sites (not reported in the tables above). The evidence here points very strongly to the fact that individuals coming to the sites are specifically looking for the site, rather than stumbling on it accidentally via interest in another topic or group. The search engine Google.co.uk is the most commonly visited sites prior to arrival and the most commonly search terms preceding visits are the party or blog names. One notable exception here is LH where it is Conservative blogger Iain Dale's blog spot that proves to be the key 'upstream' site. This overlap between Labour blog readers and Iain Dale could reflect simply Dale's highly dominant presence within the party/blogosphere. However, given that this cross-over does not appear to occur among LDV or $\mathrm{CH}$ blog readers it suggests that the site has lost its core left-wing audience and consists now mainly of Tory supporters monitoring the opposition.

Closer analysis of blog audiences was possible through a survey fielded by the authors (in conjunction with the Hansard Society's e-democracy programme) of LDV users. This survey was posted on the LDV site between 19 September and 20 October 2009 and 
attracted 129 respondents. Participants were self-selected and recruited through a link posted on the blog by contributing editor Mark Pack. Given the self-selecting nature of the sample, we anticipated that they would constitute a core group of participants in the site rather than casual users. The findings support this, with 88 percent of respondents reporting that they visited the site either daily or a few times a week. Demographic data show respondents were overwhelmingly male $(85.3 \%)$, younger $(68.2 \% 44$ years of age or younger) and educated to degree level (70.5\% with a university diploma, degree or postgraduate qualification). Respondents also displayed a strong similarity in levels of political interest and active support for the Liberal Democrats. All respondents reported their interest in politics as seven or higher on a zero to ten point scale and nine in ten $(\mathrm{N}=113)$ were strong or moderate supporters of the Liberal Democrats. Three quarters of the sample $(\mathrm{N}=94)$ had voted Liberal Democrat in 2005. Party membership was also high with 73 percent $(\mathrm{N}=94)$ of respondents reporting that they were currently members of the Liberal Democrats. Nine percent $(n=12)$ reported being members of other parties, and less than one in five $(n=23)$ had no party membership.

As well as profiling the social and political composition of LDV users we were also interested in learning more about the motives of these individuals in accessing the site. A range of alternatives were offered (as presented in Table 4) about the value of the site and individuals were asked to rate the importance of each on a scale of 0 to $10 .^{5}$

\section{[TABLE 4 ABOUT HERE]}

The results suggest that a primary function of LDV, at least for its regular users, is accessing party related news and information and discussion rather than taking action to promote any particular causes or issues. Respondents valued the site mostly as a source of news (mean score 7.42) and for engaging with the wider views within the party (mean score 7). The least important reason was to find out more about how to get involved with offline political actions 
(mean score 3.52), and finding out more about possible online political action and resources scored only slightly higher. Of the remaining reasons, being part of a wider community and getting involved in discussion and debate were seen as of moderate importance. Given that we only have user data from one of the blogs being analyzed it is important not to generalize these conclusions too far. In short, they suggest that the core audience for these sites is a group of younger male politico's who share the ideological outlook of the blog authors and who use the site to stay 'in the loop' of party affairs, rather than providing a space to take political action.

\section{Hyperlink Networks: Online Integration?}

Our final methodological tool to investigate the relationship between party blogs and parties was a network analysis of the hyperlinks connecting them. Issue Crawler harvested the hyperlink data and defined the networks of interest. These networks were then imported into NodeXL which allowed us to map and visualize the closeness and composition of the sites surrounding key actors

Our first step in understanding the linking practices of the main political parties and associated blogs was to construct a snowball network from three simple seed sets made up of pairs of homepages of official party websites and the main unofficial blogs. A snowball network simply highlights all of the websites that have been linked to from the seed set. We don't report the details in full here but one finding was important for refining our method for a more sophisticated network analysis. We found a heavy presence of links between the parties and ostensibly non-political but well known Web 2.0 services. Across the whole of the Conservatives' official site, for instance, 2850 separate links were found to the Conservatives' Flickr profile highlighting pictures of key party figures in various photo opportunity poses. Similarly, Labour's official website linked more to Twitter and Facebook than any other site (484 and 478 links respectively) and the Liberal Democrats' linked most 
to YouTube and Facebook (both with 343 links). These sets of links primarily constituted official parties highlighting their own presence in these social networks. These findings suggest that major parties at least are making strong efforts to extend their visibility within more informal online arenas and away from their own 'shop windows'.

For a more detailed analysis of hyperlink networks we utilized larger seed sets that included the profiles of both official parties and blogs on the most popular social media platforms (e.g. Twitter, Facebook, YouTube). The goal is to identify a cohesive 'issue network' that is marked by reciprocity of linking, rather than simply a list of linked websites. Crawls were launched first in May 2010 and repeated in October 2010. Following Issue Crawler's co-link technique, the seed sites are crawled and those sites that do not receive two or more links from the resulting network are removed. The websites identified in the resulting networks were coded manually according to the type of actor they represented, using categories as defined in Table 5.

\section{[TABLE 5 ABOUT HERE]}

Some basic structural properties of the three networks are presented in Table 6. Here we see that parties produced networks of broadly similar sizes in the pre-election period. The Conservatives' issue network is a little smaller and more densely connected while the low number of site-to-site links and the low network density score for the Liberal Democrats is suggestive of a rather diffuse network lacking internal coherence. The changes in network size and density in our post-election crawls are explored further in tables 6 and 7.

\section{[TABLES 6 AND 7 ABOUT HERE]}

Turning to the substance of the issue networks in terms of actor types (Table 7) we can see that they generally contain more official party sites than any other category with post-election Labour being the exception here. Party and independent blogs constitute significant components of the networks. The figures in parentheses in Table 7 report the densities of the 
links among the different categories of websites (i.e. the proportion of all possible site-to-site links in a network that actually do exist). From this it is clear that the Labour and Conservative party blogs and independent blogs are more densely interconnected than official websites. The blog networks are also fairly diverse in that they frequently feature 'opposition' sites. Labour's pre-election network, for example, includes both $\mathrm{CH}$ and Iain Dale's blog, both of which are more central than LL and LH (see Figure 3 below). So, in the build up to the election, blog authors' linking practices created a dense network of news and opinion resources that crossed party lines. ${ }^{6}$ While most people may well have got their information about parties from the official sites (as indicated in the pre-election audience statistics above), those who did visit the blogs would have been presented with many more enticements to consider a wider variety of information sources, including those of political opponents.

Figures 1-3 present the data from Table 7 in visual form and particularly allow for comparison over our two time periods; i.e. pre- and post-election. ${ }^{7}$ The results shown that for the Conservatives and the Liberal Democrats there are significant changes between the two time points while the Labour network remained more static. The diagrams present several kinds of information: nodes are scaled by in-degree centrality and represented by symbols that indicate their category (key in Table 5 above); ties are weighted by the number of links between each pair of nodes. Finally, while the network statistics in Tables 6 and 7 include websites that are in very peripheral parts of the network, where they may emit links to key network actors but receive none, the diagrams only include websites that receive links (i.e. indegree centrality $>0)$.

\section{[FIGURE 1 ABOUT HERE]}

In the top half of Figure 1, while the official site (conservatives.com) is prominent, the presence of large square nodes in the Conservatives network near the centre of the graph indicates the importance of blogs (both party and independent) in structuring the conservative 
issue network. The blogs are further connected to a periphery of smaller nodes representing news media and NGO websites. The post-election picture, however is rather different: although a few blogs stand out (notably CH, Iain Dale and Guido Fawkes' order-order.com) the official party site has become central to the network and there is an increase in the overall volume of official party sites. In terms of in-degree, the two blog categories together were the targets of $52.4 \%$ of all in-links in the network in May, but only $29.1 \%$ in October. Conversely, official party sites counted for only $6.2 \%$ of network in-links in May but $37.0 \%$ in October.

\section{[FIGURE 2 ABOUT HERE]}

In Figure 2 we see some interesting changes in the nature of the Liberal Democrats network before and after the election. In the immediate lead-up to the election central official party sources dominate (in the form of libdems.org.uk and nickclegg.com) although a number of Web 2.0 sites and independent and party blogs give the network some diversity. Post-election there appears to be a clear parting of the ways with a densely connected mass of official party sites occupying almost a separate network to that of the bloggers. In fact, while the number of official party sites receiving in-links in the network rose from 21 to 35 over time, the proportion of network in-links they account for rose from $43.2 \%$ to $83.4 \%$ and the density of links within this group increased from 0.18 to 0.52 . These trends are interesting in terms of what they indicate about the impact of governing office for each parties' online presence. Essentially, within the Conservative issue network, the official party site appears to assert a stronger authority post-election but retains a connection with the blogosphere. For the Liberal Democrats, a separation appears to have emerged between the two.

\section{[FIGURE 3 ABOUT HERE]}

Finally, in Figure 3 we see less pronounced changes in the Labour network over time. Table 7 had shown a drop in the number of official party sites and a rise in the number of NGOs. The 
latter, mostly representing trade unions of left-leaning think tanks, have increased from 4 to 13 sites that receive in-links (or 2 to 8 if we only include those that receive as well as emit links). The proportion of network links that NGOs receive has grown from $3.5 \%$ to $20.5 \%$ of the total network links. The increasing importance of this group, along with an increase in the centrality of independent blogs at the expense of party ones, suggests that contestation over the future policy direction of the Labour party has brought a greater diversity of voices into online debate.

\section{Discussion and Conclusions}

Drawing these findings together we can provide some answers to our original research questions about the purpose and significance of these new party blogs within British politics. In terms of their origins and purpose these sites are clearly designed to provide an alternative to party politics 'as usual'. While their producers are sympathetic to the parties with which they are linked and populate their sites with issues and content generated by party affairs they are ultimately motivated by a desire to see parties 'doing things differently', particularly with regard to bringing new voices into party debates, beyond the traditional members and leaders. The findings from our content analysis and survey suggest that the blogs are succeeding in providing alternative spaces for grassroots voices and sources of internal debate and criticism within the parties, although there are varying degrees of editorial control exercised. Overall, the sites do not appear to be serving as 'rival' platforms for organizing activism among ordinary supporters. Whether this continues longer term is clearly an open question. One possible longer-term effect of these blogs' arrival into party politics is the decline of geographically based localized activism. This was certainly a theme arising from the interviewees consulted for this paper. As one put it "Is having a membership base for a party the most important thing these days? No it's not actually. It's more important that a party knows who its supporters are.' Another similarly queried the value of traditional members 
pointing instead to:

...the concept of being a friend of the party, where you can have things without having to pay. ... The more you're open as a party, the more you move away from being a membership-based party and become kind of much more fluid, a party based on a coalition of interests... (Interviews with authors, $2 \& 4$ December, 2008).

While they may not as yet be replacing parties mobilizing and organizing role, it does appear that the blogs may be siphoning attention away from the parties within the wider electorate during 'normal' i.e. non-election periods. Audience figures indicate the blogs are more popular than their respective party sites in 'peace time' although during elections, the parties' appeal increases quite sharply. The network analysis enriches this picture in that it shows that parties and blogs largely inter-connect with one another during the election period to form fairly coherent and dense issue partisan networks. Thus, one might expect a degree of mixing of the audiences between the sites. However, post-election, the issue networks of the governing parties reduced in size with the blogs becoming somewhat more separate and less central. This shrinkage may be reflective of a more (small c) conservative approach by the governing parties toward their linkage partners and a desire to avoid the controversy and adversarial politics that blogs are seen to represent (Kahn and Kellner, 2005; Ceren, 2006).

Overall, therefore, we would argue that our findings show that $\mathrm{CH}$ and its Labour and Liberal Democrat counterparts are not weakening established party politics by offering new form of remote affiliation and activism but that they do serve as new and important platforms for internal dissent toward party leaders and policies. The most well known and popular of the sites, $\mathrm{CH}$ exhibits a strong professionalized ethos and acts more as a news source than as a catalyst for activism. Since assuming governing office, however, the role and prominence of the blogs within the wider party issue networks explored here does appear to have receded with official party sources becoming more central and self-referential. The extent to which this continues through the life of the current government is one that is worth returning to for 
future research.

\section{References}

Adamic, L., and N. Glance (2005): "The Political Blogosphere and the 2004 U.S. Election:

Divided They Blog," in LinkKDD '05: Proceedings of the 3rd International workshop on

Link discovery. ACM Press, New York, USA.

Bimber, B. and R. Davis. (2003). Campaigning Online: the Internet in U.S. Elections. Oxford University Press: Oxford.

Budge, I. (1996). The New Challenge of Direct Democracy. Cambridge: Polity Press.

Ceren, O. (2006). 'Oppositional Politics: Activism and the Structure of the Blogosphere' Paper presented at the annual meeting of the International Communication Association, Dresden International Congress Centre, Dresden, Germany 16 June, 2006.

Foot, K. and S.M Schneider. (2006). Web Campaigning. MIT Press: Boston.

Author (2008b)

Author. (1999).

Hansard Society (2008) Connecting with Constituents, Hansard Society: London.

Hindman, M., Tsioutsiouliklis, K., and Johnson, J. (2003). 'Googlearchy': How a few heavily-linked sites dominate politics on the Web. downloaded from http://hindman.cc/.

Jackson, N. and D. Lilleker (2008) 'MPs and E-representation: Me, MySpace and I', British Politics, 4 (2): 236-264.

Lipow, A. and P. Seyd. (1996). 'The Politics of Anti-Partyism.' Parliamentary Affairs, 49 (2): $273-284$. 
Lofgren, K. and C. Smith. (2003). 'Political Parties and Democracy in the Information Age.' In Gibson, R.K., Nixon, P.G. and S.J. Ward (eds), Net Gain? Political Parties and the Internet, Routledge: London, 39-52.

Lusoli, W., and Jankowski, N. W. (Eds.). (2005). 'The World Wide Web and the 2004 European Parliament Election.' Special issue: Information Polity, 10 (3/4).

Author (2003).

Author (2004).

Margetts, H. (2006). 'The Cyber Party', in R.S. Katz and W. Crotty (eds.) Handbook of Party Politics, Sage: London, 528-535.

Needham, C. (2005). 'Do Parties Have a Future?' Parliamentary Affairs, 58 (3): 499-502.

Negroponte, N. (1995). Being Digital. Coronet: London.

Norris, P. (2002). Democratic Phoenix: Reinventing Political Activism. CUP: Cambridge.

Rheingold, H. (1994). The virtual community: homesteading on the electronic frontier. New York, NY: Harper Perennial.

Rogers, R. (2006) “Mapping Web Space with the Issue Crawler,” unpublished ms., Available at http://www.govcom.org/publications/full_list/issuecrawler_1oct06_final.pdf

Saglie J. and K. Heider. (2005). 'Democracy within Norwegian Parties: Complacency or Pressure for Change.' Party Politics, 10 (4): 385-405.

Seyd, P. and P. Whiteley. (2002). High Intensity Participation: The Dynamics of Party Activism in Britain. University of Michigan Press: Ann Arbor.

Smith, C. (1998). 'Political Parties in the Information Age: From Mass Party to Leadership Organisation.' In Snellen, I. and W. van de Donk (eds), Public Administration in the Information Age: A Handbook, IoS Press: Amsterdam, 175-190. 
Smith, C. (2000). 'British Political Parties: Continuity and Change in the Information Age.' In Hoff, J., Horrocks, I. and Tops, P. (eds), Democratic Governance and New Technology, Routledge: London, 57-70.

Smith, C.F. and C. Webster (1995). 'Information Technology in Political Parties.' Paper presented to the Political Studies Association Annual Conference, University of York. Author (2008a).

Webb, P. (2006). 'Political Parties and Democratic Disconnect: A Call for Research.' In Webb, P. (ed.), Democracy and Political Parties, Hansard Society: London. 


\section{Endnotes}

${ }^{1}$ Given the primarily factual nature of the coding undertaken (quantity, source, frequency of postings) the content analysis was performed by one of the authors across both time periods.

${ }^{2}$ The survey was fielded in conjunction with the Hansard Society and hosted using the online survey tools provided by Survey Monkey. The full questionnaire is available from authors upon request.

${ }^{3}$ Issue Crawler is an online hyperlink analysis tool made available by Richard Rogers and colleagues at the GovCom Foundation, for more information see http://issuecrawler.net/ and Rogers (2006). NodeXL is a template for Microsoft Excel which has a range of embedded tools for quantitative social network analysis and the creation of network graphs. It was created by Marc Smith and a team at Microsoft Research; for more information see http://nodexl.codeplex.com/.

${ }^{4}$ In 2009, Alex Hilton bought Labourhome back from Mike Danson; the site was then shut down after the general election 2010 and is about to be sold off. It should be relaunched in the coming months.

${ }^{5}$ Note: all questions other than demographics were voluntary. Reported figures are calculated from valid responses on the individual questions (i.e. sample size varies and may be less than 129)

${ }^{6}$ This inter-linkage pattern contrasts with the findings of division by Adamic and Glance (2005) during the 2004 Presidential election. Their study showed that the US blogosphere was sharply ideologically divided with bloggers, particularly those on the right or conservatives side of the spectrum, tending to link only to those from the same ideological side.

${ }^{7}$ All figures below were created using the Harel-Koren fast multiscale (force directed) algorithm, as implemented in NodeXL. 
Table 1: Range and Volume of Posts and Authors

\begin{tabular}{|c|c|c|c|c|c|c|c|c|}
\hline \multirow[b]{2}{*}{ Party Blog Site } & \multicolumn{2}{|c|}{ Posts } & \multicolumn{2}{|c|}{ Posters } & \multicolumn{2}{|c|}{ Editors' Posts } & \multicolumn{2}{|c|}{ Elected Reps Posts } \\
\hline & May 2010 & Oct 2010 & May 2010 & Oct 2010 & May 2010 & Oct 2010 & May 2010 & Oct 2010 \\
\hline $\begin{array}{l}\text { Conservative } \\
\text { Home }\end{array}$ & 160 & 113 & 22 & 38 & 132 & 75 & 3 & 7 \\
\hline Lib Dem Voice & 118 & 73 & 13 & 32 & 110 & 41 & 1 & 6 \\
\hline Labour List & 57 & 51 & 18 & 26 & 36 & 27 & 0 & 4 \\
\hline Totals & 335 & 237 & 53 & 96 & 278 & 143 & 4 & 17 \\
\hline
\end{tabular}


Table 2: Tone of Posts

\begin{tabular}{|c|c|c|c|c|c|c|c|c|c|c|}
\hline Party Blog & \multicolumn{2}{|c|}{ Supportive } & \multicolumn{2}{|c|}{ Opponent Focused } & \multicolumn{2}{|c|}{ Neutral/ Non-Partisan } & \multicolumn{2}{|c|}{ Challenging/ Critical } & \multicolumn{2}{|c|}{ Other } \\
\hline Site & May 2010 & Oct 2010 & May 2010 & Oct 2010 & May 2010 & Oct 2010 & May 2010 & Oct 2010 & May 2010 & Oct 2010 \\
\hline $\begin{array}{l}\text { Conservativ } \\
\text { e Home }\end{array}$ & $56 \%(90)$ & $41 \%(46)$ & $22 \%(35)$ & $16 \%(18)$ & $18 \%(29)$ & $20 \%(23)$ & $1 \%(2)$ & $14 \%(16)$ & $3 \%(4)$ & $9 \%(10)$ \\
\hline $\begin{array}{l}\text { Lib Dem } \\
\text { Voice }\end{array}$ & $53 \%(63)$ & $44 \%(32)$ & $19 \%(22)$ & $4 \%(3)$ & $25 \%(29)$ & $24 \%(17)$ & $1 \%(1)$ & $17 \%(12)$ & $3 \%(4)$ & $11 \%(8)$ \\
\hline Labour List & $53 \%(30)$ & $34 \%(17)$ & $11 \%(6)$ & $32 \%(16)$ & $32 \%(18)$ & $30 \%(15)$ & $2 \%(1)$ & $4 \%(2)$ & $4 \%(2)$ & 0 \\
\hline Totals (n) & 183 & 95 & 63 & 37 & 76 & 55 & 4 & 30 & 10 & 18 \\
\hline
\end{tabular}


Table 3: Alexa Basic Site Statistics (May 2010 \& Nov 2010) ${ }^{a}$

\begin{tabular}{|c|c|c|c|c|c|c|c|}
\hline & $\begin{array}{l}\text { Conserva- } \\
\text { tive Party }\end{array}$ & $\begin{array}{l}\text { Conserva- } \\
\text { tive Home }\end{array}$ & $\begin{array}{c}\text { Labour } \\
\text { Party }\end{array}$ & $\begin{array}{l}\text { Labour } \\
\text { Home }\end{array}$ & Labour List & $\begin{array}{l}\text { Liberal } \\
\text { Democrat } \\
\text { Party }\end{array}$ & $\begin{array}{c}\text { LibDem } \\
\text { Voice }\end{array}$ \\
\hline \multicolumn{8}{|c|}{ Overall Traffic Rank ${ }^{\mathrm{b}}$} \\
\hline May 2010 & 42,628 & 56,051 & 56,673 & 332,453 & 206,326 & 50,055 & 167,887 \\
\hline Nov 2010 & 152,718 & 104,072 & 132,435 & 519,018 & 215,073 & 247,049 & 157,474 \\
\hline \multicolumn{8}{|c|}{ UK Traffic Rank } \\
\hline May 2010 & 798 & 1,360 & 996 & 20,586 & 10,524 & 713 & 4,697 \\
\hline Nov 2010 & 7,579 & 3,175 & 9,188 & 118,383 & 9,769 & 10,524 & 5,305 \\
\hline \multicolumn{8}{|c|}{ Change No. Visits (over 3 months) ${ }^{c}$} \\
\hline May 2010 & $+193 \%$ & $+75 \%$ & $+265 \%$ & $+4 \%$ & $+28 \%$ & $+325 \%$ & $+107 \%$ \\
\hline Nov 2010 & $-64 \%$ & $-32 \%$ & $-49 \%$ & $-34 \%$ & $+0.2 \%$ & $-71 \%$ & $-29 \%$ \\
\hline \multicolumn{8}{|l|}{ Inlinks $^{\mathrm{d}}$} \\
\hline May 2010 & 1,578 & 919 & 1,276 & 276 & 311 & 1,077 & 401 \\
\hline Nov 2010 & 1,816 & 919 & 1,490 & 276 & 327 & 1,300 & 555 \\
\hline
\end{tabular}

a Dates of data collection May 2, 2010 Nov 1-2 2010.

b Figures are calculated from registered Alexa Toolbar users (volume of unique URL visits and pageview requests), plus other sources (unspecified) over a rolling 3 month period and are updated weekly. Rankings are reported for top level domains only. Rankings below 100,000 are seen as unreliable and differences are not statistically meaningful. Scarcity of data for these sites means their ranking may be subject to large swings.

c Figures are Alexa statistics for unique visits to homepages, standardized as percentage of global Internet (as rep orted 15.08.09).

${ }^{d}$ Inlinks are crawled and indexed by Alexa generally two to three times per month. They do not count links from 'link farms' or 'exchanges' in their calculations or from sites that have no traffic. 
Table 4: Importance of Reasons for using Lib Dem Voice

\begin{tabular}{|c|c|c|c|c|c|c|}
\hline & To keep up to date & $\begin{array}{l}\text { To be part of wider } \\
\text { political community }\end{array}$ & $\begin{array}{c}\text { Find out more about } \\
\text { offline political } \\
\text { actions }\end{array}$ & $\begin{array}{l}\text { Find out more about } \\
\text { online political action }\end{array}$ & $\begin{array}{c}\text { To become more } \\
\text { aware of wider views } \\
\text { in the party }\end{array}$ & Discuss and Debate \\
\hline Mean & 7.42 & 6.03 & 3.52 & 4.42 & 7 & 5.59 \\
\hline Median & 8 & 7 & 3 & 5 & 7 & 6 \\
\hline Mode & 8 & 7 & 0 & 6 & 8 & 8 \\
\hline $\mathrm{N}$ & 119 & 120 & 120 & 120 & 120 & 118 \\
\hline
\end{tabular}

Source: LDV User Survey How important are the following reasons for visiting the site? (On a scale of 0-10) 


\begin{tabular}{ll}
\hline \hline Name & Description \\
\hline $\begin{array}{l}\text { Official Party } \\
\text { Site }\end{array}$ & $\begin{array}{l}\text { Websites maintained by the political party in one guise or } \\
\text { another. Can include sites which are not part of the party } \\
\text { homepage but are still linked to the party such as separate } \\
\text { campaign sites. }\end{array}$ \\
Oovernment & Official government websites \\
NGO/TU & $\begin{array}{l}\text { Websites maintained by external groups such as charities, } \\
\text { pressure groups, think tanks or trade unions }\end{array}$ \\
Independent & $\begin{array}{l}\text { A blog run by an individual who is not part of a formal } \\
\text { party structure, i.e. not an elected official or party } \\
\text { employee. }\end{array}$ \\
Party Blog & $\begin{array}{l}\text { A blog run by a party employee or an elected } \\
\text { representative }\end{array}$ \\
News Media & $\begin{array}{l}\text { News media sources including both mainstream and more } \\
\text { specialist news. }\end{array}$ \\
Aneb 2.0 Service & $\begin{array}{l}\text { A new media site focused on user generated multimedia } \\
\text { content (e.g. Youtube) or social networking (e.g. } \\
\text { Facebook). }\end{array}$ \\
\hline \hline
\end{tabular}


Table 6: Three Issue Networks, Overview Data

\begin{tabular}{l|cc|cc|cc}
\hline \hline & \multicolumn{2}{c}{$\begin{array}{c}\text { Conservatives } \\
\text { (Set 1) }\end{array}$} & \multicolumn{2}{c}{$\begin{array}{c}\text { Labour } \\
\text { (Set 2) }\end{array}$} & \multicolumn{2}{c}{$\begin{array}{c}\text { Liberal Democrats } \\
\text { (Set 3) }\end{array}$} \\
& May 10 & Oct 10 & May 10 & Oct 10 & May 10 & Oct 10 \\
\hline $\begin{array}{l}\text { No. Sites in } \\
\text { Network }\end{array}$ & 55 & 34 & 62 & 56 & 67 & 72 \\
$\begin{array}{l}\text { No. Site-to- } \\
\begin{array}{l}\text { Site Links in } \\
\text { Network }\end{array}\end{array}$ & 433 & 127 & 343 & 278 & 266 & 1433 \\
$\begin{array}{l}\text { Network } \\
\text { Density }\end{array}$ & 0.146 & 0.113 & 0.091 & 0.090 & 0.060 & 0.280 \\
\hline \hline
\end{tabular}

Table 7: Types of website in issue networks (No. Sites and Group Density)

\begin{tabular}{l|cc|cc|cc}
\hline \multicolumn{1}{c}{} & \multicolumn{2}{c}{$\begin{array}{c}\text { Conservatives } \\
\text { (Set 1) }\end{array}$} & \multicolumn{2}{c}{$\begin{array}{c}\text { Labour } \\
\text { (Set 2) }\end{array}$} & \multicolumn{2}{c}{$\begin{array}{c}\text { Liberal Democrats } \\
\text { (Set 3) }\end{array}$} \\
& May 10 & Oct 10 & May 10 & Oct 10 & May 10 & Oct 10 \\
\hline Official Party & 5 & 15 & 18 & 10 & 21 & 45 \\
Site & $(0.110)$ & $(0.171)$ & $(0.065)$ & $(0.078)$ & $(0.174)$ & $(0.518)$ \\
Government & 3 & 1 & 1 & 1 & 1 & 1 \\
& $(0.500)$ & $(\mathrm{N} / \mathrm{A})$ & $(\mathrm{N} / \mathrm{A})$ & $(\mathrm{N} / \mathrm{A})$ & $(\mathrm{N} / \mathrm{A})$ & $(\mathrm{N} / \mathrm{A})$ \\
NGO/TU & 5 & 2 & 4 & 13 & 0 & 2 \\
Independent & $(0.100)$ & $(0)$ & $(0.250)$ & $(0.115)$ & $(\mathrm{N} / \mathrm{A})$ & $(0.500)$ \\
Blog & 7 & 2 & 8 & 7 & 1 & 8 \\
Party Blog & $(0.405)$ & $(1.000)$ & $(0.232)$ & $(0.262)$ & $(\mathrm{N} / \mathrm{A})$ & $(0.089)$ \\
& 12 & 5 & 13 & 10 & 6 & 11 \\
News Media & $(0.409)$ & $(0.100)$ & $(0.308)$ & $(0.178)$ & $(0.100)$ & $(0.127)$ \\
Web 2.0 & 15 & 1 & 9 & 9 & 1 & 0 \\
Service & $(0.110)$ & $(\mathrm{N} / \mathrm{A})$ & $(0.042)$ & $(0.208)$ & $(\mathrm{N} / \mathrm{A})$ & $(\mathrm{N} / \mathrm{A})$ \\
Unclassified & 4 & 5 & 6 & 4 & 12 & 4 \\
Total & $(0)$ & $(0.100)$ & $(0.267)$ & $(0)$ & $(0.159)$ & $(0.167)$ \\
\hline \hline & 4 & 3 & 3 & 2 & 25 & 1 \\
& $(0)$ & $(0)$ & $(0)$ & $(0)$ & $(0.007)$ & $(\mathrm{N} / \mathrm{A})$ \\
& 55 & 34 & 62 & 56 & 67 & 72 \\
\hline
\end{tabular}


Figure 1: Conservative Issue Networks (Seed Set 1); Top: May 2010; Bottom: Oct 2010.
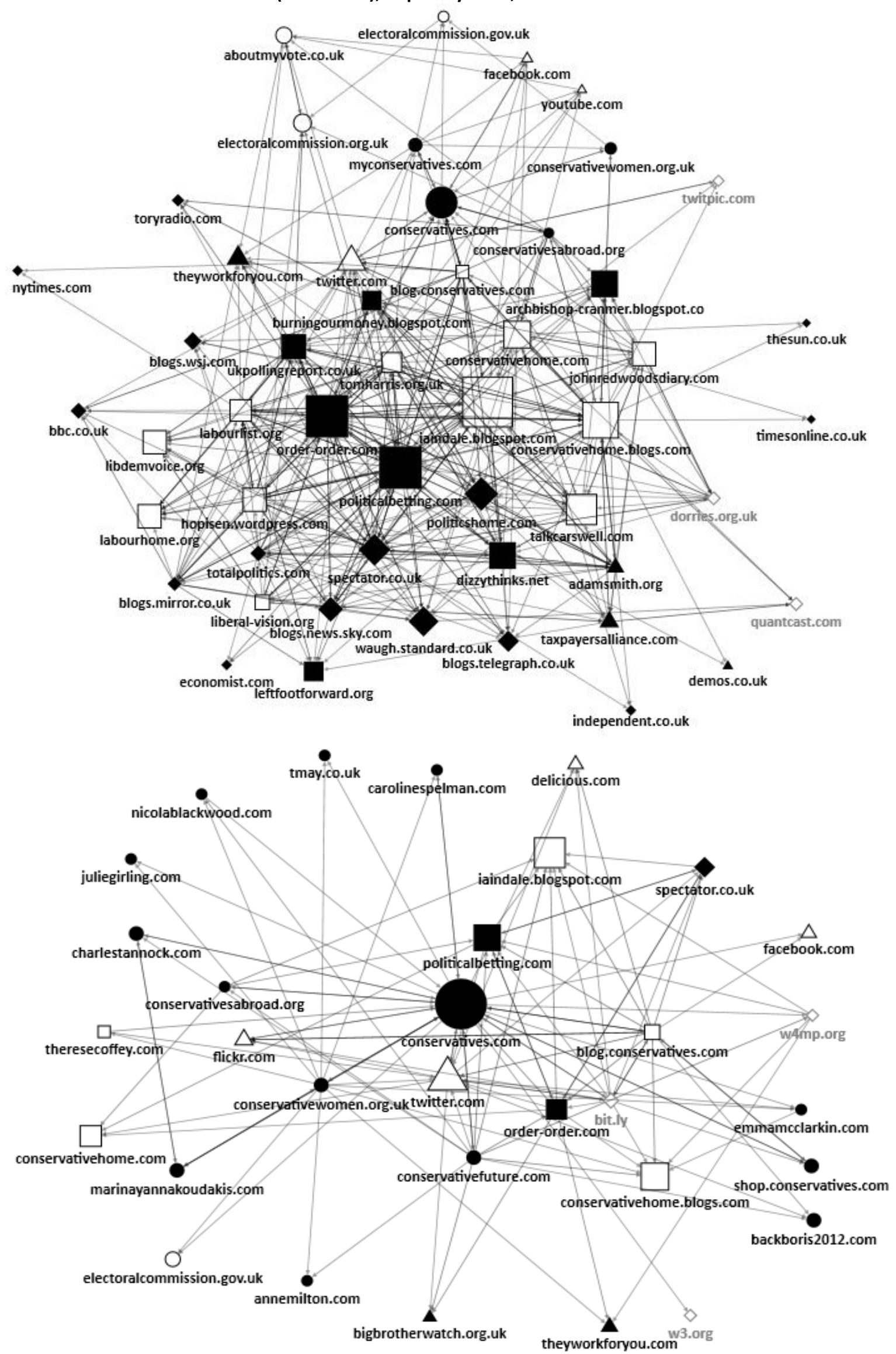
Figure 2: Liberal Democrat Issue Networks (Seed Set 3); Top: May 2010; Bottom: Oct 2010.

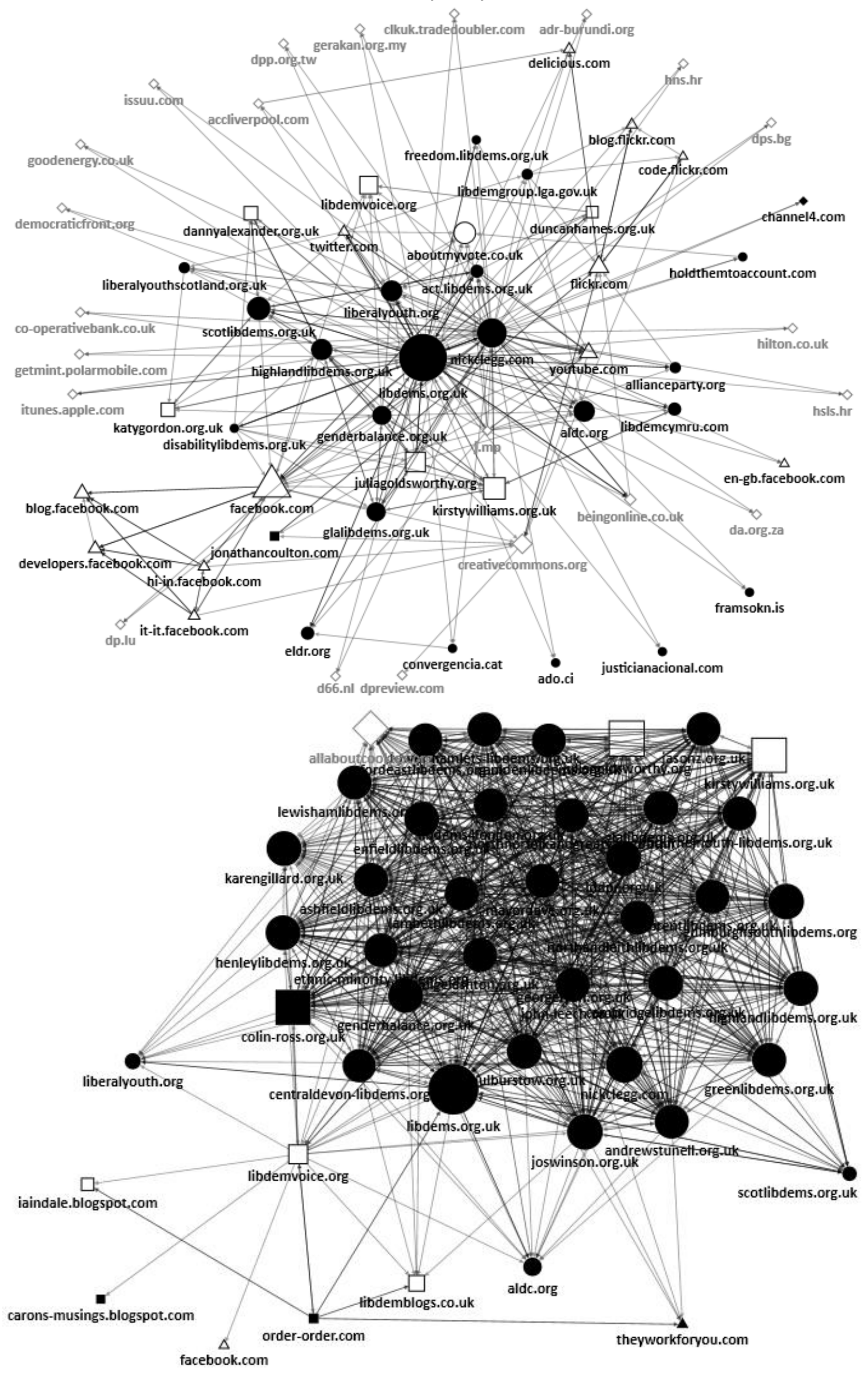


Figure 3: Labour Issue Networks (Seed Set 2); Top: May 2010; Bottom: Oct 2010.
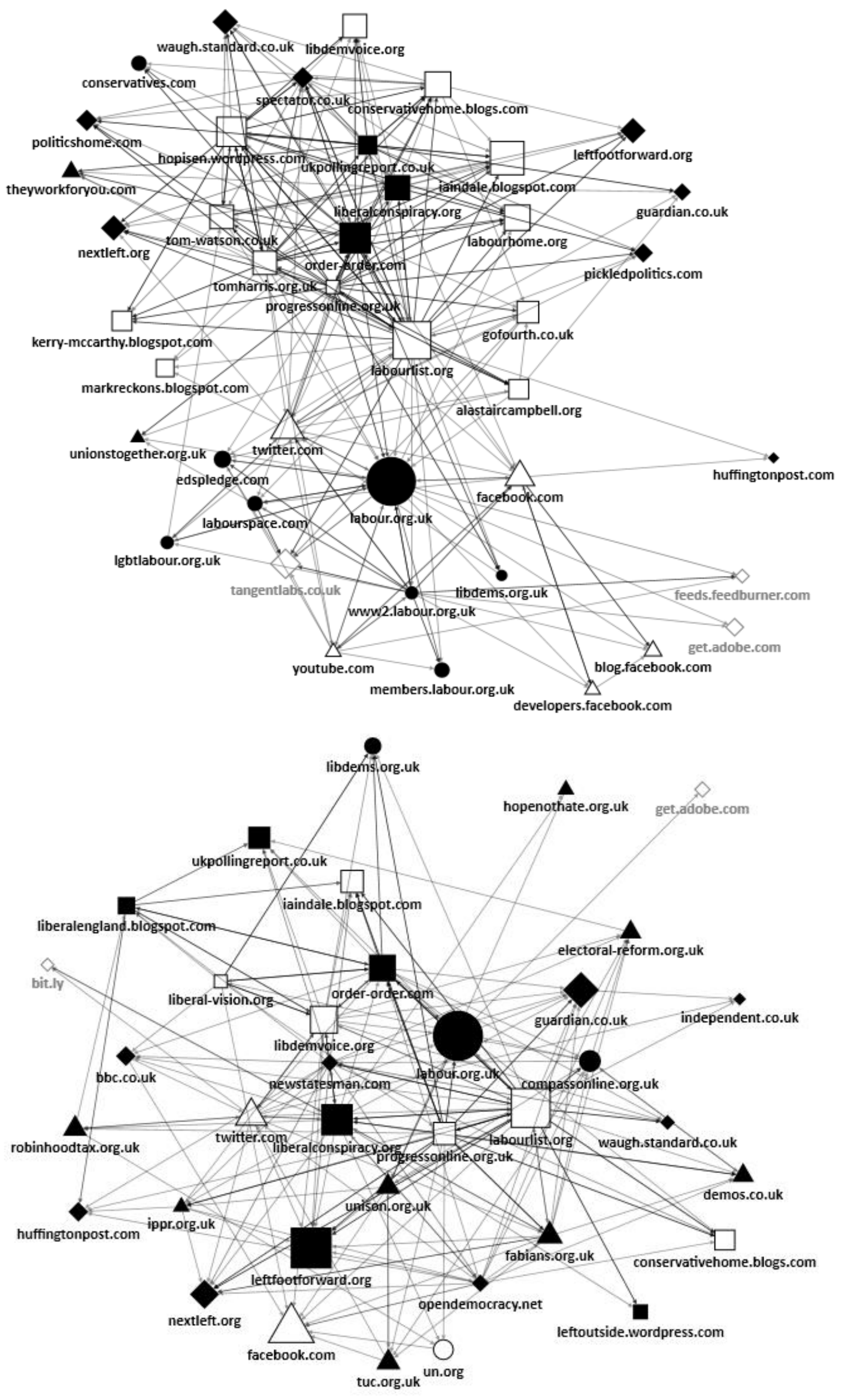


\section{Appendix: Seed Sets for Party Network Analysis}

We constructed seed sets for each of the main political parties, including official party websites, party blogs and the relevant profiles on Web 2.0 sites wherever all three parties linked to official profiles on those sites.

\begin{tabular}{|c|c|c|c|}
\hline & 1. Conservative party and blog sites & 2. Labour party and blog sites & 3. Liberal Democrat party and blog sites \\
\hline Party homepage & www.conservatives.com & www2.labour.org.uk & www.libdems.org.uk \\
\hline Party Members Area & www.myconservatives.com & members.labour.org.uk & member.libdems.org.uk/liberaldemocrats \\
\hline Party Facebook Wall & www.facebook.com/conservatives & www.facebook.com/labourparty & www.facebook.com/libdems \\
\hline Party Twitter & twitter.com/conservatives & twitter.com/UKLabour & twitter.com/LibDems \\
\hline Party Youtube Channel & www.youtube.com/webcameronuk & www.youtube.com/labourvision & www.youtube.com/user/LibDem \\
\hline Party Flickr Site & www.flickr.com/photos/conservatives & www.flickr.com/photos/uklabour & www.flickr.com/photos/libdems \\
\hline Blog & conservativehome.blogs.com & www.labourlist.org & www.libdemvoice.org \\
\hline Blog Facebook Wall & $\begin{array}{l}\text { www.facebook.com/group.php?gid=227149 } \\
4420\end{array}$ & www.facebook.com/pages/LabourList & www.facebook.com/LibDemVoice \\
\hline Blog Twitter Page & twitter.com/TimMontgomerie & twitter.com/LabourList & twitter.com/libdemvoice \\
\hline Blog Youtube Channel & www.youtube.com/user/ConservativeHome & www.youtube.com/user/LabourList & youtube.com/user/libdemvoice \\
\hline
\end{tabular}

